\title{
Community Media in the context of European media policies ${ }^{1}$
}

Núria Reguero Jiménez.

Communication Institute, Autonomous University of Barcelona

Salvatore Scifo

European Union Institute, Marmara University/Communication and Media Research Institute, University of

Westminster

\section{Abstract}

In the last three decades the emergence and development of Community Media across Europe has been mainly characterised by the political and social contexts at the national levels and, consequently, the sector is shaped by a range of opportunities and challenges that depend on the status of current policy, legislation and funding regimes in each country. Where at the pan-European level the Council of Europe has been supporting Community Media as a means for pluralism and diversity in the media, as well as a tool to promote social cohesion, in the European Union audiovisual and media policy community media have been largely overlooked. In 2008 the Culture and Education Committee of the European Parliament promoted a report to support Community Media in the Union, signalling a new development that aims to influence media policy discussion in the member states. This article aims to trace the contours of community media's route across European media policies to assess how its practice has been shaped so far and discuss the emerging issues that are likely to influence its near future.

\footnotetext{
${ }^{1}$ This article is partly based on an update of Reguero Jimenez, Núria; Sanmatin Navarro, Julián (2008), Community Media in European Union Communication Policies (2004-2008). Barcelona: European Communication Research and Education Association (ECREA), 25-28 November 2008 and on chapters of the ongoing doctoral research of Scifo, Salvatore The development of community radio in Britain (1997-2007), based at the Communication and Media Research Institute, University of Westminster.
} 


\section{Positioning Community Media}

Whatever sociological baggage 'community' brings in its train, its meaning when associated as a prefix with media or radio is determined by a set of political and bureaucratic definitions that place the resultant medium in an oppositional or at least contrasting position in relation to mainstream media. This guarantees it a position in the margins where life is hard, funding is precarious and keeping the station on air and supplied with programming is the over-riding concern. (Lewis, 2002:52)

British scholar and long-time community media activist Peter Lewis places community media firmly in the 'oppositional' or 'contrasting' position, and the language - the rhetoric of community media, shall we say - is usually telling. TV and radio stations that fall into the category described by Lewis have been named linguistically in different ways, highlighting a particular characteristic that has been seen as relevant in their own contexts. In the case of Western Europe, in Italy and France the emphasis has been placed on 'libere' and 'libre' (free) and later on 'associatif (associative); in Spain on 'comunitarios' (proximity); in the Netherlands on 'lokale' (local); in the Scandinavian countries on 'naer' (neighbourhood). With regards to its position towards regulation, it has also been defined as 'illegal' or 'pirate' and, finally, with regards to particular social groups, 'student', 'university', 'campus', 'hospital', 'diasporic' or 'ethnic' radio. (see AMARC, online, 2008; Carpentier et al., 2003,Girard, 1992; Jankowski with Prehn, 2002; Lewis\&Booth, 1989)

Is this just a matter of language? Not necessarily. Prehn has argued that 'the different terms are not only due to linguistic differences, but are also based on ideological and conceptual distinctions' (1992, 256) and Lewis (2005), drawing on similar lines, that 'in each region of the world the history and context of political struggle and cultural marginalization has determined the particular emphasis and terminology'.

Where the diversity of definitions has surely not helped to speed the sector's recognition at the wider continental level, neither facilitate communications with its stakeholders in its audiovisual and media policy lobbying actions, its diversity in practices and its potential for the achievement of social and 
cultural objectives has managed to help stations to exist in contexts where media policy and regulation have been slower to respond to community media campaigners requests.

\section{European community media lobbying: FERL and the early stages}

After the experimental and free radio bloom in the 1970s (Jankowski et al. 1992; Lewis\&Booth, 1989) community media practitioners had, or were starting to, found local and national umbrella organisations by the mid-1980s: they included OLON (Netherlands), the Association for Local Radio and Television (Denmark), the Community Radio Association (CRA, Britain), the National Association of Community Broadcasters (Ireland), Videotram and ALO-VEBE (Belgium), Emissores Municipals de Catalunya (EMUC, Catalonia, Spain), and the Association Nationale de Radio Libres Noncommerciales (France) (Prehn, 1992: 253). These organisations were established to represent the interests of the sector 'at a period when commercial interests were securing frequencies' (ibid.). But the sector still lacked regional and global representatives, and the initial step in this sense was the first World Conference of Community Radio-oriented Radio Broadcasters (WCCORB) held in Montreal in August 1983. The event had the merit to make its participants aware of being part of what had then become a global movement (Lewis, 1984), including over 400 participants from 60 countries (Reynolds, 1988). The success was replicated in 1986 in Vancouver, where Irish community radio activist Sally Reynolds became the representative for Western Europe with the task of build up contacts and networking in collaboration with newly constituted FERL (Federation Européenne de Radio Libres/European Federation of Community Radios). The Federation, also set up in 1986, included a group of 15 community radio stations from Great Britain, Switzerland, Spain, Greece and France, based in Forcalquier, France, home to the radio libre Radio Zinzine. These two developments at the continental level were important as they signalled the start of an attempt to coordinate responses to European institutions in the field of media policy. 
In its Declaration of Principle, released following a meeting on 2-3 August 1986, FERL refers primarily to Article 10 of the European Convention of Human Rights (ECHR), a key document promoted by the Council of Europe (online, 2003), to position community radio as tool to exercise the freedom of expression and, as also stated by UNESCO, as an alternative to the 'established world information order' (UNESCO, 1980). Given the precarious situation for the sector, at least in the countries present at the meeting, the participants felt the need of 'a coordinated response from European community radios' and set up a federation aiming to 'organise and mobilise solidarity wherever the need arises in Europe or afield', to become 'an official representative body at regional, national and international levels' and with the 'first and foremost priority to defend those community radios threatened by repressive legislation or by commercial interests' (FERL, 1988:1). In June 1987 FERL received an initial small grant from the European Commission and, among other things, established a Committee of Patrons to help spread awareness about the sector, this including Sean MacBride, journalists, intellectuals, academics as Michele and Armand Mattelart, members of the Swiss, French and British parliaments and the British Labour Party MEP, Glyn Ford. 1988 had been declared the European Cinema and Television Year by the EEC, but, at it is still much the case two decades later, media and audiovisual policy were primarily including measures to support cinema and television, and public and private broadcasters, with local and community stations pretty much left at the outer fringe of the system. Just before the end of the year, Ford did lodge a motion, co-signed by other seven MEPs, for a resolution on community radio (European Parliament, 1987). The motion took as preamble Article 10 of the ECHR, noting the presence of community radio in the then 12 member states, highlighting the absence of legal bases for these stations. It claimed a positive impact on local community and minority groups to have a tool for their communicative needs not satisfied by the existing public and private broadcasters and the need for central public and state support, at that time available in France and the Netherlands, as in other countries they were relying only on local audience's, authorities' and associations' support. The motion did then call for a European investigation 'into the legal, technical and economical conditions of local radio stations'; asked for guarantees for the recognition and the 
development of community radio; requested a budget line to support community media productions, similarly to the one already existent for audiovisual production, the organisational coordination of the 'third sector' and, finally, demanded a suspension to all the juridical prosecution of community radio stations across the EC until a vote on the motion (FERL 1988: 70). The text was approved by the Parliament on 28 April 1989, rapporteur the Italian MEP Roberto Barzanti (European Parliament, 1989).

The description, based as it is on emerging practices of community broadcasters across Europe, was certainly flavoured by its attempt to distinguish CR as different from mainstream broadcasting. It recalled the Universal Declaration of Human Rights and, specifically, set communication as a fundamental human right: it asserted not only the 'access' or the right to reply present in public and commercial broadcasting, but the possibility of having one's own tool to exercise this right, independent from politics, institutions and commercial interests, run not for profit and owned, managed and produced by a group that is representative of a community of place or of interest.

Community broadcasting between the 1970s and the 1980s has to be seen also in the overall context of the deregulation processes that were taking place across Western Europe. In France and Italy the authorities legalized local radio already in 1981 (a detailed account is given in Lewis\&Booth 1989: 138162), where in other parts of the continent decisions were going to be taken after a period of experimentation. The experiments were generally aiming 'to assess the viability of community oriented stations operating within a limited geographical area $(. .$.$) were to function without advertising and to be$ open for input from residents in the area (1992: 252).

The findings emerging from the report 'Local Radio and Regional Development' (Crookes and VittetPhilippe, 1986) outline the challenges faced by the community radio stations operating in the first half the 1980s. Echoing similar concerns expresses earlier by FERL, the authors did claim that community radio stations were threatened if not by extinction, then at least by relegation to second-rate status $(. .$. faced with the encroachment of commercial radio operators' and, in order to survive, 'forced to seek 
refuge in militant positions at the margins of the system $(\ldots)$ or to renounce to their principles and to court advertising revenues' (ibid., 14). The snapshots provided by the studies covering Italy, France, Belgium and the United Kingdom showed 'the breadth and the depth of talent that has previously been untapped' (155) through local small scale broadcasting at increasingly reducing costs. As the Council of Europe had promoted freedom of expression through the press, the authors argued, this concept should be then extended to freedom of the air, 'providing a simple framework of technically necessary regulation and guaranteeing the greatest possible diversity of access the citizen to the local medium' (ibid., 159-60).

The recommendation of the authors to European policymakers included: a) the granting of licences to a wide range of operators, that should be as diverse as possible, also to avoid the formation of monopolies within a region and increase the pluralism of voices; b) stations subject to the law, with the same advertising and broadcasting standards as the public and commercial operators, and 'suitable agreements' for copyright fees payments; c) encouragement for a diversity of finance options, including 'the allocation of money from a regional development fund', given their role in the development of local areas (ibid.). As for the latter point, already in 1984 the Standing Conference of Local and Regional Authorities in Europe had adopted a resolution (no.152) on 'local radio and television stations in Europe' that supported local radio and television stations as 'a significant element in local democracy', asking national, regional and local authorities 'to favour broadcasting stations which produce programmes on regional and local affairs' and ensure that 'access to airwaves and the new means of communication is as wide as possible' (quoted in FERL 1988: 71).

A Council of Europe (CoE) resolution supporting local radio (Parliamentary Assembly 1991) was among the core themes discussed at the FERL congress in May 1991 in Austria, attended by almost three hundred practitioners from seventeen countries from Western and Eastern Europe, an event also supported by the CoE, whose meaning was not only 'symbolic', but showing the positive results of working together with the Council, according to FERL (FERL 1991, 20). 
The conference proceedings show that university radio, intercultural communication (with the extended case study of AGORA, a project involving station from neighbouring areas of Austria, Italy and Slovenia) and the difficult position of community radio between the state and the market were the three areas on which discussion focused. At this time, the interventions at the local level were mainly twofold: lobbying for recognition in Western European countries where member stations were already active as Spain, Austria and Germany, but also delivering training projects and connecting with civil society organisation in countries as Czechoslovakia, Romania and the Soviet Union (ibid. 67-68). Importantly, at the previous Congress held in France in August 1989, FERL had approved a 'Charter of the Free Radios' that outlined the philosophy and the requests of the sector (ibid., 74-75). The Charter did emphasize the right to freedom of expression for citizens through free radio, independency from commercial interests and the need for a separate set of frequencies for the sector. It also requested that they fees and taxes should be waived, that they should be given a special status in the broadcasting system and that these stations should be consulted for any changes affecting them in national media and telecommunications policy.

\section{AMARC comes to Europe}

In 1990, after the conferences held in Canada and Nicaragua, the global community radio conference AMARC 4 arrives in Europe, hosted by the National Association of Community Broadcasters (NACB) in Dublin. The AMARC representative for Western Europe at that time was the Irish community media activist Sally Reynolds, this surely helping the local community radio movement to be connected to international debates on community radio and contribute to shape Irish media policy and legislation (Day, 2008). Many European practitioners had been attending the previous AMARC conferences, and experiences and programmes had been shared before then, but this occasion surely helped the sector to further contextualise its practices in the wider global context. It was not casual then that regional branch of AMARC International, AMARC Europe was founded in 1991, and in 1993 the UK-based Community Radio Association was given the mandate to establish an European Secretariat by 
AMARC, with Steve Buckley (its Director) appointed to coordinate the Western European branch activities. This was perhaps the culmination of international links forged since the participation of CRA delegates to the AMARC assemblies in Canada ten years earlier. The necessity of a European branch had been discussed since the 1988 AMARC conference in Managua and the 1990 Dublin conference had been preceded by a gathering of Europe-based members, with a mandate given to the Dutch local media association OLON that was not developed further. The European Secretariat was established at the CRA headquarters in Sheffield in 1994 and Buckley (2007) explains how this marked the start of a series of meetings across Europe with the aim to start of articulate the different interests of AMARC's European members in a coherent force at continental level. They wanted to bridge the peculiarities of Britain's Restricted Service Licence (RSL) broadcasting stations with, on the other side, experiences like the Milan-based Radio Popolare broadcasting to over 7 million people, as well as the very politicised French sector and very unpoliticised Dutch sector. In Britain the European experiences were used to support the argumentation that the sector was strong elsewhere in Europe (e.g. large funding schemes in France; recognition of a distinct community media sector in France, Ireland and The Netherlands) and pack this in lobby and advocacy materials directed to the British Government. Buckley (ibid.) remarks that it was 'good that the CRA role here was central as it did help to have knowledge on the situation elsewhere’.

The work towards a common approach to Community Radio Policy at continental level was concretised by the agreement on a 'Community Radio Charter for Europe' (AMARC, online, 1994) approved at the 1994 First Pan-European meeting of AMARC in the Slovenian capital Ljubiana. Even though the main work was driven by its Irish members, Buckley recalls that important contributions were given also from other European members. In Ireland, things went even further, with the Charter becoming integral part of the legislation and regulation as an Annex and part of the contract the licensed stations had to sign with the Irish regulator, the Broadcasting Commission of Ireland (BCI, online, 2008). 
Among other things, the Charter says that CR should try to promote the right to communicate and provide access to training, production and distribution facilities that would lead to programmes for the benefit, entertainment, education and development of its listeners. The stations should be established as organisations run not for profit and ensure their independence by being financed from a variety of sources, and managed by a body representative of the local geographical communities or of the communities of interest. Finally, they should be editorially independent of government, commercial and religious institutions and political parties in determining their programme policy, and provide the right of access to minorities and marginalised groups, therefore promoting and protecting cultural and linguistic diversity. The Charter also emphasises the use of media training for the development of its listeners/producers, including groups marginalised and neglected by mainstream media, including ethnic minorities. Day highlights the difficulties in what, after the collapse of the Eastern European regimes had become an even more fragmented community media landscape:

This declaration grew out of a lengthy process of consultation during which the differences in the historical, political, social, economical and cultural contexts of community radio station in Western Europe and in the states emerging from communist regimes in Eastern Europe became apparent. Some of these different understandings include civil society, a move from collective communist understandings of development to a highly individualistic capitalist mode of working, a mistrust of authorities and a lack of experience of working in a free speech environment for the Eastern Europeans. (Day, 2008: 20-21)

What is it that emerges from these definitions - other, that is, from a general and admirable commitment to letting a thousand voices bloom? Perhaps most clearly, it is a concern about the role of the targeted community in the radio production process, in its dual role as listener/producer, in order to have editorial control over the broadcast content. Therefore, its organisational structures have to permit to the community a substantial influence on station's policies and administration. Advertising is permitted, as long as it contributes only to cover the running costs, without being envisaged as a source of pure profit. As for the transmission footprint of the station, this can be variable, depending on local specifications. They all share the concern of giving representation to social groups that are underserved, 
marginalised, neglected or misrepresented from mainstream media from the local up to the international level.

The new decade opened with the establishment of a second European office of AMARC in Budapest in February 2000, with the aim to coordinate more closely activities in Central and Eastern Europe. In the initial year they included a regional meeting to improve networking, exchange information and experiences and develop a Plan of Action for further cooperation within the region (AMARC-Europe, online, 2000a)' and to organise the Third Pan-European conference (the second being held in Copenhagen in 1996) held in Balaton Fured in October, titled 'Radio Building Bridges' (AMARCEurope, online, 2000b).

AMARC's European Secretariat operated until 2002, when financial and administrative difficulties caused its shutdown (AMARC-Europe, online, 2000c), and has been going through re-organisation since the AMARC 9 conference in Amman until its most recent pan-European conference, held in Bucarest in December 2008 (see also Milan's piece in this issue for a report on this event; and Diasio for AMARC Europe future perspectives).

\section{A human rights approach to media: the Council of Europe}

Among the players in European policymaking, the Council of Europe (CoE) had been interested since the early 1970s in the role of media in the promotion of a more democratic society. A large number of monographs were commissioned since 1973 in a period where experiments in local cable radio and television broadcasting had been gathering pace in Western Europe, including over fifty publications in the area of local, regional and community radio and television, as well as animation and public initiatives. This was signalling the exponential increase of activity in the continent, but also the growing interest in Strasbourg to produce information for 'all those concerned in this field (...) because they have responsibility for defining communication and cultural activity policies'. A comprehensive review of these studies, published at the start of the following decade (Beaud, 1980), offers a picture of both 
access and decentralisation initiatives of the public broadcasters, as well as grassroots media selfmanaged by their own communities. The publication aimed also to address community media practitioners and circulate those experiences at a time where similar experiences in North America had been followed with great interest. Great attention was given to the challenges and opportunities arising from self-managed grassroots experiences in terms of organisation and finance, highlighting their democratic credentials, but also the risks of rising professionalism undermining the sector at that time. The much discussed decentralisation of public broadcasting was seen with suspicion as 'often, all that is done is to transfer to a local level those same power relationships that are denounced at the level of mass media' (ibid.,179), echoing ongoing concerns reported then by the MacBride Commission (UNESCO, 1978). What we see here then, is a 'space' opening for community radio in global and continental discussions on communications policy, both as a tool for access and participation in local broadcasting, as well as the counterbalancing North-South flows (see UNESCO, 1980). Those issues had been debated by the Council of Europe since it had set up a Committee of Experts to discuss media-related issues in 1976, which later became the Steering Committee on the Mass Media (CDMM) in 1981, also with the aim to address freedom of expression and information. The CDMM was composed by representatives of member countries and observers of international organisations, the Parliamentary Assembly and European organisations of public and private broadcasting. First starting under the administrative responsibility of the Directorate of Legal Affairs, the Committee was then moved to the Directorate of Human Rights, in line with a similar approach taken by UNESCO. Consequently, the Council of Europe, linked media strongly to human rights and supported the argument that they should be used also to encourage the expression of minorities and local and regional identities. The Declaration on the Freedom of Expression and Information, adopted in 1982 by the Committee of Ministers, stated among other things that 'the existence of a wide variety of independent and autonomous media' would help to reflect 'the diversity of ideas and opinions' in its member states and broadened the freedom of expression and information. (Council of Europe, 1982) 
Where the Council of Europe had been very active during the period of experimentation in local and community broadcasting in the 1970s, it paid less attention to this area in the following decade, beginning to re-consider this matter in the 1990. In 1990 its Parliamentary Assembly published a report 'On the situation of local radio in Europe' and, as a follow up, passed a resolution on January 1991: 'local radio is an ideal potential means of fostering freedom of expression and information (...) Member states not yet having done so should accordingly permit local radio to exist' (Parliamentary Assembly 1991b, quoted in Prehn 1992, 265). The cultural and communicative rights of minorities are also a focus of the CoE agenda and, among others, its Parliamentary Assembly had encouraged the establishment of media through which minority groups could receive 'appropriate information in their languages'. Moreover, the Council of Europe feels the need to reaffirm 'the existence of a multiplicity of autonomous and independent media outlets at the national, regional and local level", including 'subsides for media entities printing or broadcasting in a minority language' (Council of Europe 1999) in order to enhance pluralism of voices and local democracy. By the start of the new century the CoE reaffirmed the importance of cultural diversity through its Declaration of the Committee of Ministers adopted on 7 December 2000. (Council of Europe, online, 2000)

Community Media's contribution to strengthening freedom of expression and information was promoted in the CoE's report Transnational media concentrations in Europe (Council of Europe, online, 2004), which stated that these media are especially important since the opinions they advocate almost never reach transnational media channels (ibid.,27). For those reasons, the text encouraged the Member States' contribution to the sector's development. The next year, as a result of the study Integration and Diversity: The New Frontiers of European Media and Communications Policy (Council of Europe, online, 2005a), the Committee of Ministers adopted an the resolution carrying the same name, which resolved to promote linguistic and cultural diversity in the media paying attention to minority groups and 'minority community media' (art. 6).

In January 2007 its Committee of Ministers adopted the Declaration of the Committee of Ministers on Protecting the Role of the Media in Democracy in the Context of Media Concentration (Council of Europe, online, 
2007a), stressing that policies designed to encourage the development of not-for-profit media can help to promote pluralism (art.V), and the Recommendation CM/Rec (2007)2 of the Committee of Ministers to member states on media pluralism and diversity of media content (Council of Europe, online, 2007b), proposing to the Member States encourage the development of other media as 'community, local, minority or social media' (art. 4). The recommendation also emphasizes the role these media play as a factor of social cohesion and integration. In 2008 the CoE published the study Promoting Social Cohesion. The Role of Community Media (Lewis, online, 2008), which describes existing measures to support third sector media -highlighting the role it plays in social cohesion, especially for minority ethnic, migrant and refugee communities.

The last action taken by the CoE when closing this article has been the publication of the Declaration of the Committee of Ministers on the role of community media in promoting social cohesion and intercultural dialogue (Council of Europe, online, 2009a). Adopted at the $1048^{\text {th }}$ meeting of the Ministers' Deputies held on $11^{\text {th }}$ February 2009, it advices about the recognition of community media in national legislations and recommends the granting of specific funding and frequencies, both analogic and digital, to the sector. The declaration also recalls the importance of a wide variety of free and independent media as a ways of improving democratic societies and suggests exchanging good practices. This text and the vote in the European Parliament plenary session on $25^{\text {th }}$ September 2008 (European Parliament, online, 2008a) signed a landmark development in Community Media Policy in the continent.

\section{The European Parliament and the Resetarits Report}

In an historical analysis of the European Parliament 'limits and remits' in the field of media policy, Sarikakis has remarked how there has been 'a consensus that media issues are too important to be left to competition policy' (2005:164, see also Sarikakis, 2004). In line with this role, the adoption of the Resetarits Resolution on Community Media in Europe (European Parliament, online, 2008a), considers community media as a bottom-up solution to promote pluralism and other democratic rights, such as the participation of citizens in public spaces. It originates from a mandate given by the Committee on 
Culture and Education (COM-CULT) - responsible for audiovisual, information and media policy, and the cultural and educational aspects of the Information Society - to the Member of the European Parliament (MEP) Karin Resetarits (Alliance for Liberal and Democrats in Europe, Austria). The content of the Resolution was informed by the results of The State of Community Media in the European Union (European Parliament, online, 2007a) commissioned by the Committee. The report painted a fragmented picture of community media across the European Union -which largely depends on each Member State's history and media regulation- outlining the sector's contributions to public interest objectives as media pluralism, social inclusion, local empowerment and cross-cultural dialogue. The point of view adopted by the document, which stressed the opportunity of the analogue switch-over to use the radio spectrum more efficiently and to achieve a more transparent and accountable regulation, contrasts with a context in which the market -media and telecommunications companies- have been pushing to lead the transition to digital media broadcasting (see Hallett and Hintz in this issue for an analysis of the opportunities and challenges for community media in the transition to digital broadcasting). In fact, its recommendations about catering to the diverse audiovisual needs of the Union, taking account of the 'specificities of community media' (European Parliament, online, 2007a: 28), have been implemented in few EU member states, and mostly across its western members. On the other hand, the study underlined the appropriateness of using community media as a vehicle towards EU social and cultural policy implementation.

Based on the report's outcome, and in line with the Council of Europe, the 2008 Resolution on Community Media promotes and asks for the recognition, and where possible consolidation, of the 'third media sector', alongside public and commercial broadcasting, highlighting its contribution to the diversity of voices available in the media. The text also remarks how none of the relevant EU legal texts addresses the community media issue and requests to the European Commission and to the Member States to consider this document when defining the sector in their regulation. Based on the characteristics defined by AMARC - adopted also by the CoE-, the Parliament defines community media as communication initiatives that are non-profit and accountable to the community that they 
seek to serve, and open to participation in content production. Among the sector's societal contributions, the Resolution underlines its capacity to strengthen cultural and linguistic diversity, social inclusion and local identity. According to the text, community media can also act as a catalyst for local creativity and improving citizens' media literacy. Furthermore, it can strengthen media pluralism by balancing the decreasing localness available on commercial stations via 'traditional' broadcast, even though it has to be noted that there also contexts where commercial media have also invested strongly to develop new tools that add localised features to their websites.

Given the social capital provided by community media, the Resolution calls for EU funding resources and spectrum availability, both analogue and digital, bearing in mind that their service is not to be assessed only in terms of the justification of the cost of spectrum allocation. It also considers that the sector can help to bring the EU closer to its citizens by addressing specially targeted audiences, for instance, contributing to policies relating to Equality and Non-Discrimination as they serve disadvantaged ethnic minorities and that, therefore, its social benefits have to be taken in account.

Significantly, at the same plenary session the EP also adopted the Resolution on Concentration and Pluralism in the Media in the European Union - the rapporteur was Estonian MEP Marianne Mikko - which recommends state aid to community media so that they can 'fulfill their function in a dynamic environment'. (European Parliament, online, 2008b)

Even though these policies on community media are not binding, the Parliament has continued pressing on the issue, within the framework of media pluralism. As explained in the next section, the EP's voiced concern about media concentration processes has been taken into account by the Commission through the set up of the Task Force for Coordination of Media Affairs.

\section{The European Commission: community media and the struggle for recognition}

The main EU competences on media policy belong to the European Commission. As it will emerge in the discussion of its policies below, the Commission has to manage two complementary but often 
opposed flows of interests: deregulate and the defense if the democratic and cultural aspect of the media industry - the first being the most prominent (Michalis 2007)

Media policies are basically implemented by means of the regulatory framework, consisting of the Audiovisual Media Services Directive (AVMS) (2007/65/EC), approved in December 2007 (European Parliament, online, 2007b) and amending the former 'Television without Frontiers' (TVWF) Directive (Council of the European Communities, 1989). The TVWF Directive aimed to remove national legal and regulatory barriers to create a European single market competing with the one of the US (Humphreys, 2008). The new law keeps the market orientation while reaffirming media pluralism and 'the objective of cultural diversity', as well as the fight against racial and religious hatred, and the protection of minors.

Besides the Directive, there are other three types of actions to implement EU audiovisual policy. The second cornerstone is the MEDIA Programme, jointly run by the DG Information Society and Media and the Education, Audiovisual and Culture Executive Agency (EACEA) ${ }^{\mathrm{ii}}$. It consists in a support mechanism focusing on training professionals in the film and audiovisual industry in order to support an industry competitive at international level, where community media have been ignored so far. Other actions include the distribution of audiovisual content over electronic networks (Content On-line and Media Literacy) and Media Pluralism (Task Force for Coordination of Media Affairs, also known as Media Task Force). The main action concerning media pluralism taken by the Commission, the Task Force on Co-ordination of Media Affairs, has been set up during the $6^{\text {th }}$ legislature of the Parliament (2004-2009).

\subsection{Task Force on Co-ordination of Media Affairs}

Set up within the Directorate-General for Information Society and Media by its commissioner Viviane Reding, the Media Task Force ${ }^{\mathrm{iii}}$ responds to the Liverpool Audiovisual Conference agreement (European Commission, online, 2005) and the political concerns about media concentration, and its effects on pluralism and freedom of expression. Its action consists in a three-step plan launched in 
January 2007. The first step was the publication of the Commission Staff Working Paper on Media Pluralism in the Member States of the EU (European Commission, online, 2007a), which outlines efforts to promote pluralism by third parties and organisations - notably the essential work undertaken by the Council of Europe. Even though it refers to internal pluralism, community media are not taken into account in the document: 'Both public service and commercial broadcasters contribute to media pluralism and this dualism itself further strengthens pluralism' (ibid.,12). Moreover, the Commission's document considers that few players in a small market may not in itself threaten media pluralism and it underlines the paradox that a substantial market share (concentration) may be helpful for funding certain types of programming considered important for pluralism, such as investigative journalism. Confronting these statements with the absence of alternative and/or grassroots-produced communication channels, it can be said that the Commission Staff Working Paper maintains the unbalance created by the predominance of financial interests over participatory ones.

The political context for community media looks more positive within the second step of the Commission, namely consisting in an independent study to define and test specific indicators for media pluralism in EU Member States. Its preliminary draft, which will delineate the basis for a Commission Communication on the Indicators for Media Pluralism in the EU Member States (step three), was published in April 2009 under the title Indicators for Media Pluralism in the Member States - Towards a Risk-Based Approach (European Commission, online, 2009a). While describing the underlying assumptions made during the construction of a monitoring mechanism (European Commission, online, 2009c) it recognizes the important role in fostering cultural media pluralism played by minority and community media. Defining 'pluralism of media types' as the coexistence of different 'mandates and sources of financing, notably commercial media, community or alternative media, and public service media, within and across media sectors, like print, television, radio and internet' (ibid.,13), the document alerts that the role played by minority and community media 'depends heavily on government policies on regulation, subsidies and control' (ibid). More specifically, it states: 
Community media, such as open channels, web radio or non-profit radio, and TV stations have been developed to support plurality of opinion, create a space for local communication, and connect audiences by direct access. [...] Absence or insufficient system of minority and community media, the lack of investment in minority and community media, entry barriers for minority/community media by cable operators and other platform providers, marginal reach, lack of public support measures aiming at compensation of disadvantaged position of minorities as media users, pose threats to cultural media pluralism. (European Commission, online, 2009a: 13)

Indeed, according this study's preliminary draft, the lack of incentives for the creation and viability of such media is one of the main threats, from the legal point of view, for EU's media pluralism. Concretely, it states that 'the existing regulatory framework does not remedy entry barriers for minority and community media neither provides investment nor public support measures aiming at compensation of disadvantaged position of minorities as media producers and media users'. (ibid: 37). Threats to cultural media pluralism listed by the Media Task Force's study also includes the absence, or insufficient representation, of journalists and media executives from minority, ethnic, religious, linguistic groups in society, including women, disabled people and sexual minorities.

The first results of the Preliminary Final Report planned were discussed on 8 June 2009 along with the prototype of the Media Pluralism Monitor (MPM) and its User Guide. The meeting, addressed to regulators, NGO's, academic scholars, and market actors aimed at the formulation of conclusions and recommendations for the implementation of the report. Among other things, the research team suggested a biennial implementation of monitoring for the first time in 2010, followed by a second round in 2012.

\subsection{The Media Literacy Expert Group}

The Media Literacy Expert Group is one of the main EU actions concerning the distribution of audiovisual content over electronic networks. Community media have gone largely unnoticed among this group's targets too, although some projects have been mentioned as examples of good practices by the Commission's report Current Trends and Approaches to Media Literacy in Europe (European Commission 
Media Literacy Expert Group, online, 2007) and the communication A European approach to media literacy in the digital environment (European Commission, online, 2007c). The Community Media Network ${ }^{\mathrm{iv}}$ (Ireland), for instance, is referred as a promoter of community development and empowerment, using video, radio, photography, print and the Internet as resource tools.

Apart from the Media Task Force and the Media Literacy Expert Group, there is a range of legislative acts in the period 2004-2008 that refer tangentially to community media: the Communication on accelerating the transition from analogue to digital broadcasting (European Commission, online, 2005), and the White Paper on a European communication policy (European Commission, online, 2006a), along with the Report on the White Paper on a European communication policy (European Commission, online, 2006b) (for an analysis of these policies see also Reguero Jimenez and Sanmatin Navarro, online, 2008). The Communication on Accelerating the Transition from Analogue to Digital Broadcasting is an example of the EU media policy trends which the Parliament and the Council of Europe intend to readdress. Despite the text warning about the possible distortions in markets where digital switchover debates are underpinned by spectrum availability, -and calls to the Commission to foster a debate about the regulatory implications of the digital re-framing of the spectrum- the Communication leaves to the market demand the mission to determine the best usage of the frequencies liberated at the end of the analogue switch over. Community media have been also ignored by the White paper on a European communication policy, aiming at closing the gap between the EU and its citizens throughout a strategy based on the principles of inclusiveness, diversity in the public debate and citizens' participation. In that case, the Parliament responded with the Report on the White Paper on a European communication policy, which 'stresses the need to find a formula that involves national, regional and local media more closely in communication policy, for which the use of alternative media as a communication channel should also be considered (ibid.,8).

As shown with the examples above, community media and the not-for-profit sector in general are absent among the Commission's targets in the field of media policy. Nevertheless, the sector's 
contribution to pluralism remarked in recent statements of the Council of Europe and the European Parliament has been catered by the Media Task Force through the study on the indicators of media pluralism. This represents an improvement of the context that could lead community media to a higher ranking in the Commission's media policy agenda, and, indeed, Commission officials seem to share the Parliament's concern to provide better visibility for community media as a means of achieving social cohesion across the EU (Andrau, interview, 2008).

\section{Conclusions}

After thirty years of campaigning for spectrum allocation, funding and institutional support in Europe, both at national and supra-national levels, community media have finally found a place in European media policy at a time when the $6^{\text {th }}$ European Parliament's legislature (2004-2009) is ending its mandate. This new orientation in media policy, towards the promotion of the diversity of voices and media ownership, has been in part the result of actions at the level of the Council of Europe and, more recently, of the Parliament addressing Members States, the Commission and civil society organizations. Indeed, the ongoing debates on media pluralism would have fallen in a serious contradiction by ignoring not only community media practices, which represent themselves a bottom-up solution for pluralism. The Commission's and community media practitioners' interests have converged within the Media Task Force, which has recognised the sector's contribution to increase media pluralism. This convergence is not only important to reinforce community media's relevance among EU institutions, but also to be included them into debates about spectrum and the digital dividend. This debate is crucial for the continuity of community media activity in some Member States where their access to the spectrum is almost impossible, as in the case of Spain. There is still much to be done to make sure that, enabling environments for community media become a reality -especially in Central and Eastern Europe- and that the sector will still be part of the media landscape after the transition to digital broadcasting systems. It is Member States' own responsibility to implement the documents adopted by the Parliament and the Council of Europe, but they will surely provide an important reference for 
campaigners and activists, and their umbrella organisations, in further negotiations at national level, as well in future negotiations with the newly elected Parliament and the Commission (June 2009). Finally, the Council of Europe has outlined its Action Plan for its future work in a Conference of Ministers held in Reykjavik on 28-29 May 2009. Significantly, the President of CMFE was chosen to represent the contribution of civil society to the discussion on Relations of the media with the individual and with the community(ies) and, among other things, there was consensus among CoE's Member States to Agree on the need to remain attentive to the risks involved in a situation of strong concentration of media and media-like mass-communication services, and to the role of those services, including public service and community media, in facilitating intercultural dialogue and promoting a culture of tolerance in multicultural societies (Council of Europe, online, 2009b: 7)

The outcome of the elections and the new working arrangements of the Council of Europe, together with the monitoring of the impact of the Resetarits resolution and the document on community media adopted by the CoE in 2009, surely deserve close scrutiny from activists, policymakers and researchers alike. This will help to assess what shape 'the media of the people' (Jakubowicz, online, 2009: 3) will take in this next phase.

\section{References}

Beaud, P. Community Media? Local radio, television and audiovisual animation experiments in Europe, Strasbourg: Council of Europe, 1980

Carpentier, N., Rie, L., Servaes, J. Community Media: muting the democratic discourse? in Continuum: Journal of Media and Cultural Studies, Vol.17, No.1, London: Carfax Publishing, 2003

Crookes, P, Vittet-Philippe, P. Local radio and regional development in Europe, Manchester: European Institute for the Media, 1986

Day, R. Community Radio in Ireland: Participation and Multi-flows of Communication, New Jersey: Hampton Press, 2008 
European Parliament, Motion for a resolution on community radio stations, Series B, Document B2$1377 / 87,4^{\text {th }}$ December 1987, proposed by Glyn Ford, 1987

European Parliament, Motion for a resolution on radio and television broadcasting in the European Community, Serie A, Document A2-0153/89, $28^{\text {th }}$ April 1989, proposed by Roberto Barzanti, 1989

FERL. Euradio. Forcalquier, FERL, 1988

FERL. Freies Radio! Schlussbericht III. Kongress der FERL, Europaische Föderation Freier Radios, 16-20 Mai 1991, Wien, Universitätsverlag, 1991

Girard, B. A Passion for Radio. Radio, Waves and Community. Montreal: Black Rose Books, 1992 Humphreys, P. The principal axes of the European Union's audiovisual policy in Fernandez Alonso, I and De Moragas i Spà, M, editors, Communication and Cultural Policies in Europe. Barcelona: Generalitat de Catalunya - Càtedra Unesco de Comunicació InCom-UAB, 2008, p. 151-182

Jankowski, NW with Prehn, O.(editors) Community media in the information age. Perspectives and prospects. New Jersey: Hampton Press, 2002

Lewis, PM. Community Radio: the Montreal conference and after, Media, Culture, and Society, 1984, 6: $137-150$

Lewis, PM. Editorial, The Radio Journal - International Studies in Broadcast and Audio Media, 2005, 3 (1): 3-6

Lewis, PM. Radio Theory and Community Radio. In Jankowski. NW and Prehn, O., editors, Community Media in the Information Age, Creskill, New Jersey: Hampton Press, 2002, p.4761

Lewis, PM and Booth, J. The Invisible Medium: Public, Commercial and Community Radio, Basingstoke: Macmillan Education, 1989

Michalis, M. Governing European Communications. From Unification to Coordination, Lanham, Maryland: Lexington Books, 2007

Parliamentary Assembly of the Council of Europe, Resolution 957 on the situation of local radio in Europe, Strasbourg: Council of Europe, 1991 
Prehn, O. From Small Scale Utopianism to Large Scale Pragmatism. Trends and Prospects for Community Oriented Local Radio and Television in Jankowski, NW, Prehn, O. and Stappers, J (editors) The People's Voice: Local Radio and Television in Europe, London: John Libbey, 1992, p.247-268

Reynolds, S. AMARC in Euradio, Forcalquier, FERL, 1988

Sarikakis, K. Powers in Media Policy: The Challenge of the European Parliament, Oxford, Bern, Berlin, Brussels and Frankfurt am Main: Peter Lang, 2004

Sarikakis, K. Defending Communicative Spaces: The Remits and Limits of the European Parliament, Gazette, 2005, 67(2): 155-172

Lewis, PM. Community Radio: the Montreal conference and after, Media, Culture, and Society, 1984, 6: $137-150$

UNESCO. Interim report on communication problems in modern society. International Commission for the Study of Communication Problems, UNESCO: Paris, 1978

UNESCO. Many Voices, One World. Towards a New, More Just and More Efficient World Information and Communication Order, UNESCO: Paris, 1980

\section{Web References}

AMARC 'AMARC's Principles' [Online] Available at: http:/ / wiki.amarc.org/index2.php?topic=Amarc_principles\&lang=EN\&style=amarc\&site=a marc (accessed $12^{\text {th }}$ November 2008), 2008

AMARC 'The Community Radio Charter for Europe' [On-line] Available at:

http://www.amarc.org/index.php?p=Community_Radio_Charter_for_Europe (accessed $12^{\text {th }}$ November 2008), 1994

AMARC-Europe 'Budapest 2000 - Three major events' in Newsletter, Issue no.1, March 2000 [On-line] Available at: 
http://web.archive.org/web/20020203225951/http://www.amarc.org/europe/Publications/

Newsletter/Mar2000-en.htm (accessed $12^{\text {th }}$ April 2009), 2000a

AMARC-Europe Radios Building Bridges: 3rd Pan European Conference of Community Radio Broadcasters in Newsletter, Issue no.1, May 2001 [On-line] Available at: http://web.archive.org/web/20020209172602/http://www.amarc.org/europe/Publications/New sletter/May2001-en.html\#balat (accessed 12 ${ }^{\text {th }}$ April 2009), 2000b

AMARC-Europe 'AMARC Europe Council Statement' in Newsletter, Issue no.1, May 2001 [On-line] Available at: http://web.archive.org/web/20020209172602/http://www.amarc.org/europe/Publications/New sletter/May2001-en.html\#amarc (accessed 12 ${ }^{\text {th }}$ April 2009), 2000c

Broadcasting Commission of Ireland Licensing Radio: Community/Community of Interest: Radio Policy Document [Online] Available at: http://www.bci.ie/licensing/radio/community_policy.html (accessed $12^{\text {th }}$ November 2008), 2008

Council of the European Communities Council Directive of 3 October 1989 on the coordination of certain provisions laid down by law, regulation or administrative action in Member States concerning the pursuit of television broadcasting activities (89/552/EEC) [Online] Available at: http:/ /eur-lex.europa.eu/LexUriServ/site/en/consleg/1989/L/01989L0552-19970730-en.pdf (accessed 20 $0^{\text {th }}$ April 2009), 1989

Council of Europe Declaration on the Freedom of Expression and Information [Online] Available at: http://www.coe.int/t/dghl/standardsetting/media/Doc/CM/Dec(1982)FreedomExpr_en.asp (Accessed: $1^{\text {st }}$ April 2009), 1982

Council of Europe Recommendation 1277 (1995)1 on migrants, ethnic minorities and media. [Online] Available at: http://assembly.coe.int/Main.asp?link=/Documents/AdoptedText/ta95/EREC1277.htm (Accessed: $1^{\text {st }}$ April 2009), 1995

Council of Europe Recommendation No. R (97) 21 of the Committee of Ministers to Member states on the media and the promotion of a culture of tolerance. [Online] Available at: 
http://www.coe.int/t/dghl/standardsetting/media/doc/cm/rec(1997)021\&expmem_EN.asp (Accessed: $1^{\text {st }}$ April 2009), 1997

Council of Europe Recommendation No. R (99) 1 of the Committee of Minister to Members States on measures to promote Media Pluralism. [Online] Available at:

http://www.coe.int/t/dghl/standardsetting/media/doc/cm/rec(1999)001\&expmem_EN.asp (Accessed: $1^{\text {st }}$ April 2009), 1999

Council of Europe Declaration on cultural diversity [Online] Available at:

https://wcd.coe.int/ViewDoc.jsp?id=389843 (Accessed: 1 $^{\text {st }}$ April 2009), 2000

Council of Europe Convention for the Protection of Human Rights and Fundamental Freedoms. [Online] Available at: http://www.echr.coe.int/NR/rdonlyres/D5CC24A7-DC13-4318-B457-

5C9014916D7A/0/EnglishAnglais.pdf (Accessed: $1^{\text {st }}$ April 2009), 2003

Council of Europe Transnational Media Concentrations in Europe (AP-MD(2004)007). [Online] Available at: http://www.mainzer-medieninstitut.de/PDF_AP-MD(2004)007.pdf (Accessed: $1^{\text {st }}$ September 2008), 2004

Council of Europe Integration and Diversity: The New Frontiers of European Media and Communications Policy. [Online] Available at:

http://www.coe.int/t/dghl/standardsetting/media/Doc/MCM(2005)005_en.pdf (Accessed: 26 ${ }^{\text {th }}$ August 2008), 2005a

Council of Europe (2005b), Integration and Diversity: The New Frontiers of European Media and

Communications Policy. [Online] Available at: http://www.coe.int/T/E/Com/Files/Ministerial-

Conferences/2005-kiev/texte_adopte.asp (Accessed: 26 ${ }^{\text {th }}$ August 2008), 2005b

Council of Europe Declaration of the Committee of Ministers on Protecting the Role of the Media in Democracy in the Context of Media Concentration. [Online] Available at: https://wcd.coe.int/ViewDoc.jsp?id=1089615 (Accessed: $3^{\text {rd }}$ February 2008), 2007a 
Council of Europe Recommendation CM/Rec (2007)2 of the Committee of Ministers to member states on media pluralism and diversity of media content [Online] Available at https://wcd.coe.int/ViewDoc.jsp?id=1089699 (Accessed: 10 ${ }^{\text {th }}$ August 2008), 2007b

Council of Europe Declaration of the Committee of Ministers on the role of community media in promoting social cohesion and intercultural dialogue. [Online] Available at: https://wcd.coe.int/ViewDoc.jsp?id=1409919 (Accessed: $6^{\text {th }}$ April 2009), 2009a

Council of Europe 1st Council of Europe Conference of Ministers responsible for Media and New Communication Services - Political declaration and resolutions.. [Online] Available at: http://www.coe.int/t/dc/press/source/20090529_final_declaration_iceland_en.doc (Accessed: $30^{\text {th }}$ May 2009), 2009b

European Commission Communication of 24 May 2005 from the Commission to the Council, the European Parliament, the European Economic and Social committee and the Committee of the Regions on accelerating the transition from analogue to digital broadcasting (COM(2005) 204 final). [Online] Available at: http://eurlex.europa.eu/LexUriServ/LexUriServ.do?uri=COM:2005:0461:FIN:EN:PDF (Accessed: $7^{\text {th }}$ May 2008), 2005

European Commission White paper on a European communication policy (COM (2006) 35 final) [Online] Available at: http://europa.eu/documents/comm/white_papers/pdf/com2006_35_en.pdf (Accessed: 4th July 2008), 2006a

European Commission Report on the White Paper on a European communication policy (2006/2087(INI).

[Online] Available at:

http://www.europarl.europa.eu/sides/getDoc.do?type=REPORT\&mode=XML\&reference=A62006-0365\&language $=\mathrm{EN}$ (Accessed: 4th July 2008), 2006b

European Commission Staff Working Document on Media Pluralism in the Member States of the European Union (SEC(2007) 32). [Online] Available at:

http://ec.europa.eu/information_society/media_taskforce/doc/pluralism/media_pluralism_swp _en.pdf (Accessed: $26^{\text {th }}$ August 2008), 2007a 
European Commission Directive 2007/65/EC of the European Parliament and of the Council of 11 December 2007 amending Council Directive 89/552/EEC on the Coordination of Certain Provisions Laid Down by Law, Regulation or Administrative Action in Member States Concerning the Pursuit of Television Broadcasting Activities. [Online] Available at http://eur-lex.europa.eu/LexUriServ/LexUriServ.do?uri=OJ:L:2007:332:0027:0045:EN:PDF (Accessed: $3^{\text {rd }}$ September 2008), 2007b

European Commission Communication from the Commission to the European Parliament, the Council, the European Economic and Social Committee and the Committee of the Regions of 20 December 2007 A European approach to media literacy in the digital environment (COM(2007) 833) [Online] Available at: http://ec.europa.eu/avpolicy/media_literacy/docs/com/en.pdf (Accessed: $3^{\text {rd }}$ September 2008), $2007 c$

European Commission Indicators for Media Pluralism in the Member States - Towards a Risk-Based Approach. Leuven: Katholieke Universiteit. [Online] Available at: http://ec.europa.eu/information_society/media_taskforce/doc/pluralism/pfr_report.pdf (Accessed: 30 ${ }^{\text {th }}$ April 2009), 2009a

European Commission History of TVWF - The Television Without Frontiers Directive. [Online] Available at: http://ec.europa.eu/avpolicy/reg/history/historytvwf/index_en.htm (Accessed: 30 ${ }^{\text {th }}$ April 2009), $2009 \mathrm{~b}$

European Commission Media Pluralism Monitor. [Online] Available at:

http://ec.europa.eu/information_society/media_taskforce/doc/pluralism/pfr_annex2_mpm.xls (Accessed: 30 April 2009), 2009c

European Commission Media Literacy Expert Group Current Trends and Approaches to Media Literacy in Europe. Barcelona: Autonomous University of Barcelona. [Online] Available at http://ec.europa.eu/avpolicy/media_literacy/docs/studies/study.pdf (Accessed: $6^{\text {th }}$ April 2008), 2007 
European Parliament The Charter of Fundamental Rights of the European Union [Online] Available at:

http://www.europarl.europa.eu/charter/pdf/text_en.pdf (Accessed: $4{ }^{\text {th }}$ September 2008), 2000

European Parliament Report on the White paper on European communication policy with citizens [Online]

Available at: http://www.europarl.europa.eu/oeil/file.jsp?id=5329222 (Accessed: $4^{\text {th }}$ September 2008), 2006

European Parliament The state of community media in the European Union. Brussels: European Parliament.

Policy Department Structural and Cohesion Policies. [Online] Available at:

http:/ /www.europarl.europa.eu/activities/committees/studies/download.do?file $=22408$

(Accessed: $6^{\text {th }}$ May 2009), 2007a

European Parliament Directive 2007/65/EC of the European Parliament and of the Council of 11 December 2007 amending Council Directive 89/552/EEC on the coordination of certain provisions laid down by law, regulation or administrative action in Member States concerning the pursuit of television broadcasting activities. [Online] Available at http://eur-lex.europa.eu/LexUriServ/LexUriServ.do?uri=CELEX:32007L0065:EN:NOT (Accessed: 20 $0^{\text {th }}$ April 2009), 2007b

European Parliament Resolution of 25 September 2008 on Community Media in Europe (2008/2011(INI))

[Online] Available at: http://www.europarl.europa.eu/sides/getDoc.do?pubRef=-

//EP//TEXT+TA+P6-TA-2008-0456+0+DOC+XML+V0//EN\&language=EN (Accessed:

$3^{\text {rd }}$ October 2008), 2008a

European Parliament Resolution of 25 September 2008 on Concentration and Pluralism in the Media in the

European Union. [Online] Available at:

http://www.europarl.europa.eu/sides/getDoc.do?pubRef=-//EP//TEXT+TA+P6-TA-2008-

0459+0+DOC + XML+V0//EN (Accessed: $12^{\text {th }}$ October 2008), 2008b

Jakubowicz, K., 'A new notion of media', Keynote speech to the $1^{\text {st }}$ Council of Europe Conference of

Ministers Responsible for Media and New Communication Services [Online] Available at: 
http://www.cmfe.eu/docs/_CoE_Reykjavik_Karol_Jakubowicz_Keynote.pdf (Accessed: 30 ${ }^{\text {th }}$ May 2009), 2009

Lewis, P.M., Promoting social cohesion. The role of community media. Council of Europe: Strasbourg [Online] Available at: http://www.coe.int/t/dghl/standardsetting/media/Doc/H-Inf(2008)013_en.pdf (Accessed: $3^{\text {rd }}$ October 2008)

Reguero Jiménez, N, Sanmartin Navarro J, Community Media in European Union Communication Policies (2004-2008). European Communication Conference: Barcelona 25-28 November 2008. [Online] Available at: http://www.ecrea2008barcelona.org/guide/abstract.asp?id_callfor=1388\&id_seccion=2\&id_subse ccio $=16$ (Accessed: $1^{\text {st }}$ April 2009), 2008

UNESCO Convention on the Protection and Promotion of the Diversity of Cultural Expressions. [Online] Available at: http://unesdoc.unesco.org/images/0014/001429/142919e.pdf (Accessed: $1^{\text {st }}$ April 2009), 2005 United Nations Universal Declaration of Human Rights. [Online] Available at: http://www.un.org/en/documents/udhr/ (Accessed: $1^{\text {st }}$ April 2009), 1948

\section{Interviews}

Pierre-Yves Andrau, Legal Officer of the DG Information Society \& Media, European Commission, $17^{\text {th }}$ October 2008

Steve Buckley, President, AMARC, $4^{\text {th }}$ April 2007

Karin Resetarits, Member of the European Parliament (Alliance of Liberals and Democrats for Europe, ALDE) and Rapporteur for Community Media in Europe, 21 ${ }^{\text {st }}$ August 2008

\footnotetext{
i In the Preamble to the Directive (European Commission 2007b), paragraph 1 considers the equity of economic and cultural aspect of audiovisual media services and paragraph 5 states that it respects principles of the UNESCO Convention on the Protection and Promotion of the Diversity of Cultural Expressions (see UNESCO, online, 2005)

ii http://ec.europa.eu/information_society/media/index_en.htm

iii http://ec.europa.eu/information_society/media_taskforce/pluralism/index_en.htm

iv http://www.cmn.ie
} 